
RESEARCH AND DEVELOPMENT

\author{
http://journal.unnes.ac.id/sju/index.php/higeia
}

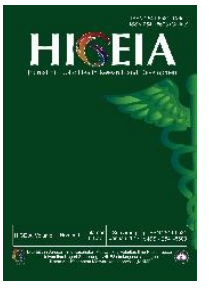

\title{
Tekanan Panas, Konsumsi Cairan, dan Penggunaan Pakaian Kerja dengan Tingkat Dehidrasi
}

\author{
Sheila Mufida Ariyanti ${ }^{1 \bowtie}$, Yuliani Setyaningsih ${ }^{2}$, Diki Bima Prasetio $^{1}$ \\ ${ }^{1}$ Program Studi Kesehatan Masyarakat, Fakultas Kesehatan Masyarakat, Universitas Muhammadiyah Semarang, Indonesia \\ ${ }^{2}$ Program Studi Kesehatan Masyarakat, Fakultas Kesehatan Masyarakat, Universitas Diponegoro, Indonesia
}

\section{Info Artikel}

Sejarah Artikel:

Diterima 21Agustus 2018

Disetujui 17 Oktober

2018

Dipublikasikan 30

Oktober 2018

\section{Keywords:}

Dehydration, Blacksmith,

Heat Pressure, Work Clothes

\section{DOI:}

https://doi.org/10.15294

/higeia.v2i4.25095

\begin{abstract}
Abstrak
Pekerja di lingkungan panas dapat terpapar dehidrasi. Selain lingkungan kerja yang panas dehidrasi dapat disebabkan oleh kurangnya konsumsi cairan, penggunaan pakaian saat bekerja dan riwayat penyakit yang dimiliki.Pekerja pandai besi Desa Hadipolo terpapar panas dari lingkungan kerja berkisar antara $30^{\circ} \mathrm{C}-35^{\circ} \mathrm{C}$ dan mengalami tanda-tanda dehidrasi. Penelitian dilaksanakan pada tanggal 7-15 April 2018.Tujuan penelitian menganalisis hubungan tekanan panas, konsumsi cairan dan penggunaan pakaian saat bekerja dengan tingkat dehidrasi pada pekerja pandai besi di Desa Hadipolo Kecamatan Jekulo Kabupaten Kudus. Penelitian ini merupakan penelitian analitik observasional dengan pendekatan cross sectional. Hasil penelitian ini ada hubungan antara tekanan panas $(p$ value $=0,036)$, konsumsi cairan $(\mathrm{p}$ value $=0,021)$, penggunaan pakaian saat bekerja $(p$ value $=0,020)$ dengan tingkat dehidrasi. Analisis secara multivariat diperoleh hasil kategori konsumsi cairan dengan $\mathrm{p}$ value $=0,016$ dan kategori penggunaan pakaian saat bekerja dengan $\mathrm{p}$ value $=0,017$. Kesimpulan dari penelitian ini variabel yang paling berperan terhadap tingkat dehidrasi yaitu kategori konsumsi cairan kategori dan penggunaan pakaian saat bekerja.
\end{abstract}

\begin{abstract}
Workers in hot environments can be exposed to dehydration. In addition to a hot dehydrated work environment, it can be caused by a lack of fluid consumption, the use of clothing at work and the history of the disease. Blacksmith workers in Hadipolo village are exposed to heat from the work environment ranging from $30^{\circ} \mathrm{C}-35^{\circ} \mathrm{C}$ and experiencing signs of dehydration. The study was conducted on April 7-15, 2018. The purpose of the study was to analyze the relationship between heat stress, fluid consumption and clothing usage while working with the level of dehydration in blacksmith workers in Hadipolo Village, Jekulo District, Kudus Regency. this research is an observational analytic study with cross sectional approach. The results of this study there is a relationship between heat stress ( $p$ value $=0.036)$, fluid consumption ( $p$ value $=0.021)$, use of clothing at work ( $p$ value $=0.020$ ) with the level of dehydration with. Multivariate analysis obtained results of fluid consumption category with $p$ value $=0.016$ and clothing usage category while working with $p$ value $=$ 0.017. The conclusion of this study is the variable that most plays a role in the level of dehydration, namely the category of consumption of liquid and clothing usage category while working
\end{abstract}

(C) 2018 Universitas Negeri Semarang 


\section{PENDAHULUAN}

Pekerja di lingkungan panas dapat terpapar dehidrasi. Selain lingkungan kerja yang panas dehidrasi dapat disebabkan oleh kurangnya konsumsi cairan, penggunaan pakaian saat bekerja dan riwayat penyakit yang dimiliki (OSHA, 2011)'(Sari, 2014)'(Horie, 2013). Menurut Briawan (2008) konsumsi air masyarakat Indonesia masih tergolong rendah, yaitu $49,1 \%$ subyek penelitian remaja mengalami kurang air atau dehidrasi ringan, pada orang dewasa sebesar $42,5 \%$. Penelitian yang telah dilakukan Sari (2017) pada 53 tenaga kerja yang bekerja di iklim kerja panas yaitu bagian weaving I dengan suhu ruangan kerja mencapai $32,22^{\circ} \mathrm{C}$ dan weaving II dengan suhu ruangan kerja mencapai $31,96^{\circ} \mathrm{C}$, ada sebanyak 37 pekerja yang mengalami dehidrasi.

Hasil penelitian yang di lakukan Hidayatullah (2016) pada pekerja yang berada di lingkungan panas diketahui pekerja yang dehidrasi sebesar 19,2\%. Hasil penelitian menunjukkan ada perbedaan tingkat konsumsi air minum antara pekerja yang terpapar iklim kerja panas diatas dan dibawah Nilai Ambang Batas (NAB) (Hasani, 2016). Hal tersebut dimungkinkan karena suhu lingkungan kerja yang tinggi $\left(>300^{\circ} \mathrm{C}\right)$ sehingga terjadi peningkatan kebutuhan cairan mencapai 6000 $8000 \mathrm{ml}$, namun ternyata hanya $2,7 \%$ subjek yang mengonsumsi cairan $>6$ liter per hari. Konsumsi cairan berhubungan dengan status hidrasi pada pekerja. Penelitian pada 30 tenaga kerja di bagian stockyard menunjukkan adanya perbedaan tingkat dehidrasi pada pekerja yang bekerja di lingkungan kerja yang memiliki tekanan panas < Nilai Ambang Batas (NAB) dan $>$ NAB (Lestari, 2016).

Menurut Tasyrifah (2017) iklim kerja panas berpengaruh signifikan pada tingkat dehidrasi tenaga kerja, dimana tingkat dehidrasi pada tenaga kerja yang bekerja dengan iklim panas bagian pengepakan $62 \%$ lebih tinggi dibandingkan dengan tingkat dehidrasi pada iklim kerja panas bagian pelintingan $38 \%$. Faktor risiko dehidrasi yaitu umur, jenis kelamin, lingkungan kerja panas, suhu tubuh, riwayat penyakit dan tingkat konsumsi cairan (Hidayatullah, 2016)'(Gustam, 2012). Pekerja di lingkungan panas seperti di sekitar peleburan, boiler, oven, tungku pemanas atau bekerja di luar ruangan di bawah terik matahari dapat mengalami tekanan panas (Apriyani, 2014). Tekanan panas merupakan batasan tubuh menerima beban panas dari kombinasi tubuh yang menghasilkan panas saat melakukan pekerjaan dan faktor lingkungan (seperti pajanan suhu lingkungan yang terlalu panas, kelembaban, pergerakan udara, dan radiasi perpindahan panas), beban fisik yang berat, waktu istirahat yang tidak mencukupi, serta pakaian yang digunakan(Harrianto, 2008)'(Horie, 2013)'(Wulandari, 2016). Panas yang ekstrim terjadi di Jepang pada pertengahan bulan Juni hingga Juli, dilaporkan kecalakaan industri yang mengakibatkan sejumlah kematian akibat sengatan panas mencapai 47 orang, angka kejadian tersebut merupakan jumlah terbesar dalam periode 23 tahun (Horie, 2013). Suhu lingkungan yang tinggi dapat menyebabkan proses pengeluaran cairan melalui keringat cukup banyak, dan kekurangan cairan eksternal atau dehidrasi dapat terjadi karena penurunan asupan cairan dan kelebihan pengeluaran cairan (Apriyani, 2014).

Pekerja yang terpapar radiasi inframerah dan matahari dapat menurunkan panas radiasinya dengan mengenakan pakaian, tetapi pada saat yang sama terjadi penurunan kapasitas pendinginan memalui evaporasi (Vanani, 2008). Kebutuhan cairan pada pekerja dalam lingkungan panas $\left(30^{\circ} \mathrm{C}-35^{\circ} \mathrm{C}\right.$ ISBB $)$ dengan intensitas kegiatan fisik aktif sampai sangat aktif adalah sebesar 6-8 Liter per hari (Hidayatullah, 2016). Dehidrasi ditandai dengan penderita berkeringat banyak, kehilangan cairan, dehidrasi, terasa lemah, dan dapat pingsan. Bila tidak mendapat tindakan medis yang cepat, gangguan kesehatan karena suhu lingkungan yang eksterm ini dapat mengakibatkan kecacatan atau kematian (Harrianto, 2008). Desa Hadipolo merupakan salah satu desa di Kecamatan Jekulo Kabupaten Kudus, merupakan desa sentral kerajinan pandai besi yang sudah turun temurun. 
Berdasarkan survei pendahuluan di Desa Hadipolo Kecamatan Jekulo Kabupaten Kudus terhadap lingkungan kerja, dimana suhu pada lingkungan kerja berkisar antara $30^{\circ} \mathrm{C}-35^{\circ} \mathrm{C}$, suhu tersebut sudah tidak nyaman lagi untuk bekerja, terlihat ada 21 orang pekerja yang tidak menggunakan pakaian saat bekerja, sedangkan suhu yang optimal untuk kerja orang Indonesia berkisar antara $24^{\circ} \mathrm{C}-26^{\circ} \mathrm{C}$. Pekerja mengalami tanda-tanda dehidrasi, terlihat dari beberapa pekerja tidak mengenakan pakaian saat bekerja dan terpapar panas terus-menerus dari tungku pembakaran. Pada saat wawancara kepada 30 pekerja, mereka mengaku sering merasa haus saat bekerja, pegal, panas, pusing dan kram tangan. Konsumsi air minum pekerja ditempat kerja rata-rata $750 \mathrm{ml}$. Asupan air yang dikonsumsi dirasa kurang untuk memenuhi kebutuhan pekerja yang bekerja dilingkungan panas.

Berdasarkan penelitian terdahulu yang telah di lakukan oleh Sari (2017), Hidayatullah (2016), Lestari (2016), Tasyrifah (2017) dan Wesseling (2016) terdapat beberapa perbedaan yaitu penelitian terdahulu menggunakan variabel konsumsi air minum, kelelahan kerja, iklim kerja, tekanan darah, dan gangguan kesehatan. Penelitian ini menambahkan variabel baru yaitu penggunaan pakaian pada saat bekerja di analisis menggunakan analisis data multivariat dan berlokasi di Desa Hadipolo Kecamatan Jekulo Kabupaten Kudus. Tujuan penelitian untuk menganalisis hubungan tekanan panas, konsumsi cairan dan penggunaan pakaian saat bekerja dengan tingkat dehidrasi pada pekerja pandai besi di Desa Hadipolo Kecamatan Jekulo Kabupaten Kudus.

\section{METODE}

Penelitian ini merupakan penelitian analitik observasional dengan pendekatan cross sectional. Penelitian difokuskan pada home industri pandai besi yang memiliki pekerja $\geq 5$ orang. Sampel penelitian diambil menggunakan cluster random sampling, yang memiliki $\geq 5$ pekerja ada 27 home industri atau kluster dan akan diambil $30 \%$ dari total populasi yaitu sebanyak 9 kluster secara acak. Setelah sampel diambil berdasarkan kriteria inklusi dan ekslusi didapatkan sebanyak 42 pekerja. Variabel independent dalam penelitian ini adalah tekanan panas, konsumsi cairan dan penggunaan pakaian saat bekerja sedangkan variabel dependent dalam penelitian ini adalah tingkat dehidrasi. Analisis data dilakukan secara univariat, secara bivariat menggunakan uji Chi Square dan secara multivariat menggunakan uji regresi logistik multivariat.

Sumber data dalam penelitian ini data yang diperoleh berasal dari dua sumber yaitu: data primer merupakan data hasil pengamatan atau data yang diolah oleh peneliti. Data primer dalam penelitian ini diperoleh langsung dari penilaian lingkungan kerja untuk mengukur tekanan panas dan pengukuran dehidrasi berdasarkan warna urin. Selain itu juga dilakukan wawancara dan observasi untuk mengetahui jumlah konsumsi air munum selama 5 jam bekerja, mengetahui penggunaan pakaian saat bekerja. Selain itu, data sekunder diperoleh dari Kantor Kepala Desa hadipolo tentang jumlah home industri dan pekerja.

Instrumen penelitian adalah perangkat yang digunakan untuk mengungkap data, sehingga data dapat dianalisis dan akhirnya dapat mencapai tujuan yang diinginkan. Instrumen penelitian yang digunakan adalah sebagai berikut: Instrumen penelitian untuk mengukur tekanan panas menggunakan alat Extech HT30 WBGT Meter berdasarkan NAB tekanan panas, instrument pengukuran dehidrasi berdasarkan warna urin menggunakan tabel warna urin, dan instrument untuk mengetahui konsumsi air dan penggunaan pakaian saat bekerja menggunakan lembar observasi dan kuesioner. Teknik pengambilan data yang digunakan dalam penelitian ini adalah pengukuran, wawancara, dan dokumentasi.

Analisis data dalam penelitian ini menggunakan analisis univariat bertujuan untuk menjelaskan atau mendeskripsikan karakteristik setiap variabel penelitian. Analisis univariat digunakan untuk mendeskripsikan tekanan panas, konsumsi cairan, penggunaan pakaian 
saat bekerja dan terjadinya tingkat dehidrasi dalam bentuk tabel distribusi frekuensi dan prosentase variabel yang diteliti. Analisis bivariat dilakukan terhadap dua variabel yang diduga mempunyai hubungan atau korelasi dengan pengujian statistik. Analisis bivariat dalam penelitian ini dilakukan untuk mengetahui hubungan dua variabel yaitu variabel bebas dan variabel terikat, dalam hal ini tekanan panas, konsumsi cairan dan penggunaan pakaian saat bekerja yang mempunyai hubungan dengan tingkat dehidrasi. Uji statistik yang dilakukan dalam penelitian ini disesuaikan dengan jenis skala datanya. Untuk melakukan analisis bivariat ini digunakan program komputer. Uji statistik dalam penelitian ini adalah uji chi square, karena analisis hubungan pada penelitian ini menggunakan variabel kategorik dengan kategorik, $\mathrm{H}_{0}$ ditolak jika $\mathrm{p}$ value $\leq \alpha$ dan $\mathrm{H}_{0}$ diterima jika $\mathrm{p}$ value $>\alpha$. Dikatakan ada hubungan apabila $\mathrm{p}$ value 0,05 . Analisis multivariat yang digunakan yaitu analisis regresi logistik multivariat yaitu untuk mengetahui hubungan antara variabel bebas lebih dari satu dengan satu variabel terikat, dimana pada variabel terikat merupakan variabel data kategorik. Analisis digunakan untuk mengetahui faktor yang berhubungan dengan tingkat dehidrasi secara bersama-sama dan dapat diketahui variabel yang paling berhubungan dan berapa besar nilai hubungan yang paling tinggi.

\section{HASIL DAN PEMBAHASAN}

Hadipolo merupakan desa di Kecamatan Jekulo, Kabupaten Kudus, Provinsi jawa Tengah. Secara geografis letak Desa hadipolo berada diantara $110^{\circ}-50^{\circ}$ BT (Bujur Timur) serta $6^{\circ}-16^{\circ}$ LS (Lintang Selatan). Desa Hadipolo merupakan desa penghasil alat-alat rumah tangga, pertukangan dan pertanian, dimana didesa Hadipolo terdapat banyak industri pandai besi yang menghasilkan pisau, cangkul, sabit, gergaji, palu, dan lain-lain.

Industri pandai besi yang berada di Desa Hadipolo ada 195 home industri dengan total pekerja 526 pekerja. Bangunan di home industri pandai besi Desa Hadipolo terdiri dari 1 lantai, beratap genteng, bagian tembok sebagian terbuat dari batu-bata dan ada, lantai bagian bawah sebagaian besar terbuat dari tanah tetapi ada juga yang menggukan plester. Jam kerja pekerja di industri pandai besi Desa Hadipolo rata-rata dimulai pukul 07.00 dan selesai pukul 15.00 .

Industri pandai besi Desa Hadiopolo masih menggunakan proses pembuatan tradisional yaitu menggunakan tungku api untuk menempa logam. Pada proses menempa pekerja terpapar panas secara langsung dari tungku api yang digunakan untuk menempa sehingga dapat menimbulkan efek kesehatan bagi pekerja.

Hasil analisis univariat masing-masing variable dapat dilihat pada tabel 1. Analisis Univariat Tekanan Panas, Konsumsi Cairan, Penggunaan Pakaian Kerja dan Tingkat Dehidrasi.

Berdasarkan penelitian yang telah dilakukan terhadap 9 home industri terdiri dari 42 pekerja industri pandai besi Desa Hadipolo, Kecamatan Jekulo, Kabupaten Kududs diperoleh hasil distribusi frekuensi tekanan panas pada 9 home industri yang dapat dilihat pada tabel 1. Diketahui ada 1 home industri $(11,1 \%)$ yang memiliki tekanan panas sesuai NAB dan 8 home industri $(88,9 \%)$ yang memiliki tekanan panas di atas NAB. Pengukuran tekanan panas pada lingkungan kerja dilakukan untuk membandingkan nilai tekanan panas yang ada di lingkungan kerja dengan standar

Tabel 1. Analisis Univariat Tekanan Panas, Konsumsi Cairan, Penggunaan Pakaian Kerja dan Tingkat Dehidrasi

\begin{tabular}{lcc}
\hline \multicolumn{1}{c}{ Tekanan panas } & $\mathrm{F}$ & $\mathbf{( \% )}$ \\
\hline Sesuai NAB & 1 & 11,1 \\
Di atas NAB & 8 & 88,9 \\
$<1$ liter & 36 & 85,7 \\
> 1 liter & 6 & 14,3 \\
1-2 hari perminggu & 15 & 35,7 \\
3-4 hari perminggu & 15 & 35,7 \\
Setiap kali bekerja & 12 & 28,6 \\
Dehidrasi tingkat & 10 & 23,8 \\
ringan & & \\
Dehidrasi tingkat berat & 32 & 76,2 \\
\hline
\end{tabular}


atau NAB. Pengukuran dilakukan di 3 titik untuk mendapatkan nilai rata-rata tekanan panas. Hasil pengukuran tekanan panas di 9 home industri dilakukan masing-masing 3 titik pengukuran didapatkan hasil rata-rata $32,29{ }^{\circ} \mathrm{C}$. Pengukuran tersebut menunjukkan bahwa tekanan panas melebihi NAB. Berdasarkan Peraturan Menteri Ketenagakerjaan Nomor 5 tahun 2018 tentang Keselamatan dan kesehatan kerja NAB tekanan panas yaitu $29,0{ }^{\circ} \mathrm{C}$ untuk jenis pekerjaan atau beban kerja dalam kategori sedang dengan pengaturan waktu kerja $75 \%$ dan waktu istirahat $25 \%$.

Seseorang yang tinggal di lingkungan yang iklimnya tidak terlalu panas maka tidak akan mengalami pengeluaran cairan yang ekstrem melalui kulit dan pernafasan. Sedangkan seseorang yang tinggal di lingkungan bersuhu tinggi atau di daerah dengan tingkat kelembapan yang rendah akan lebih sering mengalami kehilangan cairan dan elektrolit (Tamsuri, 2009). Udara yang panas dan lembab dapat membuat berkeringat sehingga membutuhkan tambahan air. Udara dalam ruangan yang panas juga dapat membuat kulit kehilangan kelembabannya (Gustam, 2012). Apabila tenaga kerja bekerja ditempat kerja yang memiliki tekanan panas melebihi NAB maka dapat mengalami efek tekanan panas. Efek tekanan panas terjadi sebagai akibat dari metabolisme tubuh dalam mempertahankan panas tubuh tidak berhasil yaitu berupa pengeluaran keringat. Kegagalan ini ditandai berupa keluhan subjektif seperti mengeluh rasa panas, banyak keringat, selalu haus, perasaan tidak enak dan hilangnya nafsu makan yang disebabkan oleh hilangnya cairan dari tubuh oleh penguapan keringat (Kukus, 2009)'(Suma'mur, 2009). Kehilangan air melalui penguapan bergantung pada suhu serta kelembaban lingkungan. Makin tinggi suhu dan makin rendah kelembaban akan meningkatkan kehilangan air (Santoso, 2011).

Distribusi frekuensi konsumsi cairan pekerja selama 5 jam bekerja diketahui ada 36 pekerja $(85,7 \%)$ mengkonsumsi cairan $<1$ liter dan sebanyak 6 pekerja $(14,3 \%)$ mengkonsumsi cairan $\geq 1$ liter. Air mempunyai fungsi dalam berbagai proses penting dalam dalam tubuh manusia, seperti pengatur suhu tubuh, zat pelarut, pembentuk sel dan cairan tubuh, pelumas dan bantalan, media eliminasi sisa metabolism (Hastuti, 2015). Konsumsi cairan sangat dibutuhkan oleh tubuh karena air memiliki banyak fungsi yang dibutuhkan oleh tubuh sebagai medium transportasi, pengatur suhu tubuh, pembentuk sel dan cairan tubuh serta sebagai pelarut. Sekitar $80 \%$ dari kebutuhan individu merupakan kontribusi dari cairan termasuk air, dan sisanya diperoleh dari makanan. Kebutuhan cairan setiap individu dipengaruhi oleh berbagai faktor seperti usia, jenis kelamin, tingkat aktivitas, faktor lingkungan, dan status gizi (normal, overweight, obesitas). Tubuh secara normal akan kehilangan air melalui paru-paru ketika menghembuskan nafas, melalui keringat, produksi kemih dan saat buang air besar. Kehilangan cairan tersebut harus diganti untuk menjaga agar kondisi dan fungsi cairan tubuh tidak terganggu (Aprillia, 2014).

Apabila air yang keluar dari tubuh tidak digantikan dengan jumlah konsumsi cairan yang cukup maka sel-sel tubuh akan kehilangan air, kehilangan air inilah yang menyebabkan dehidrasi (Tamsuri, 2009). Konsumsi air terdiri atas air yang diminum dan diperoleh dari makanan sebagai hasil metabolisme yang keluar dari tubuh termasuk yang dikeluarkan sebagai urine, air di dalam feses, dan air yang dikeluarkan melalui kulit dan paru-paru (Sari, 2017). Meminum air sebaiknya jangan terlalu banyak dan jangan terlalu sedikit paling tidak 8 gelas per harinya karena setiap fungsi tubuh diatur dan tergantung pada air (Vanani, 2008). Jumlah konsumsi cairan yang dianjurkan yaitu di mana seorang yang bekerja di tempat panas sebaiknya minum sebanyak 200-300 cc/30 menit atau setara dengan 1 gelas kemasan/30 menit (Fajrianti, 2017). Cairan yang hilang melalui keringat dan tidak diganti menyebabkan volume plasma menurun dan terjadi penurunan kemampuan fisik dan kognitif pekerja (Santoso, 2011). Pekerjaan di tempat panas harus diperhatikan secara khusus kebutuhan air dan garam sebagai pengganti cairan untuk 
penguapan. Menurut Suma'mur (2009) air minum merupakan unsur pendingin tubuh yang penting dalam lingkungan panas terutama bagi tenaga kerja yang terpapar oleh panas yang tinggi sehingga banyak mengeluarkan keringat. Kebiasaan minum air yang baik dapat mencegah terjadinya dehidrasi tubuh setelah terpapar panas dalam kurun waktu tertentu. Berdasarkan hasil pengamatan dan wawancara langsung pada pekerja yang bekerja di lingkungan panas sebagian besar responden mengkonsumsi air minum dalam rentang waktu di atas 30 menit (Apriyani, 2014).

Distribusi frekuensi penggunaan pakaian saat bekerja diketahui bahwa dari 42 pekerja hanya 12 pekerja $(28,6 \%)$ yang menggunakan pakaian setip kali bekerja. Pakaian yang digunakan pekerja saat bekerja berguna untuk melindungi permukaan tubuh dari paparan panas dan dapat mengurangi panas radiasinya. Pemilihan pakaian untuk bekerja tergantung pada lingkungan tempat bekerja, apabila lingkungan kerjanya panas maka sebaiknya menggunakan pakaian yang tipis dan bahan yang dapat menyerap keringat. Jenis bahan pakaian yang dianggap nyaman saat dipakai adalah katun. Kain katun merupakan salah satu jenis pakaian yang memiliki properti penyerapan air yang baik, menyerap kelembaban dari kulit lebih efektif daripada bahan pakaian serat sintetis sehingga dengan tingginya kemampuan jenis pakaian ini dalam menyerap air diharapkan dapat menurunkan suhu tubuh (Brazaitis, 2010)'(Davis, 2013)'(Dai, 2008) . Kondisi lingkungan kerja yang panas dan penggunaan pakaian yang tidak tepat dapat mempengaruhi tingkat keringat hingga 2,25 L/jam. Karena pemilihan pakaian yang tidak tepat dapat menghambat terjadinya konveksi antara kulit dengan aliran udara (Kenefick, 2012).

Distribusi pekerja berdasarkan tingkat dehidrasi yang diukur menggunakan warna urin setelah 5-6 jam bekerja diketahui pekerja dengan kategori dehidrasi berat sebanyak 32 pekerja $(76,2 \%)$ dan responden yang memiliki tingkat dehidrasi dengan kategori ringan sebanyak 10 pekerja (23,8\%). Dehidrasi adalah kehilangan cairan yang berlebihan dari jaringan tubuh. Apabila terjadi ketidakseimbangan cairan di dalam tubuh, maka akan timbul kejadian dehidrasi atau kehilangan air secara berlabihan (Tamsuri, 2009). Dehidrasi dapat menyebabkan efek negatif pada tubuh yang berpengaruh pada ginjal dan dapat meningkatkan metabolisme tubuh (Ningsih, 2014). Kejadian dehidrasi juga memiliki pengaruh terhadap kemampuan kinerja, baik kemampuan secara fisik maupun kemampuan berpikir. Lebih parah lagi ketika seseorang tidak mengonsumsi cairan yang cukup dan mengalami penurunan jumlah cairan tubuh sampai $10 \%$ akan berdampak pada kematian (Gustam, 2012). Seorang yang bekerja dalam ruangan mengekskresikan $200 \mathrm{~mL}$ keringat tambahan, dan bagi orang yang aktif jumlahnya lebih banyak lagi. Selain mengeluarkan air dan panas, keringat juga merupakan sarana untuk mengekskresikan garam, karbondioksida, dan dua molekul organik hasil pemecahan protein yaitu amoniak dan urea. Status hidrasi dipengaruhi oleh adanya faktor suhu lingkungan yang tinggi sehingga terjadi peningkatan pengeluaran cairan melalui pernapasan dan keringat yang menyebabkan kebutuhan cairan tubuh meningkat dan kecukupan konsumsi cairan yang sesuai dengan kebutuhan (Santoso, 2011)'(Veronica, 2010).

Hasil analisis bivariat antara masingmasing variabel dengan dehidrasi dapat dilihat pada tabel 2. Pada tabel 2. tersebut dapat diketahui bahwa variabel bebas yang berhubungan dengan tingkat dehidrasi pada pekerja pandai besi yaitu tekanan panas, konsumsi cairan dan penggunaan pakaian saat bekerja.

Hasil penelitian tentang hubungan antara tekanan panas dengan tingkat dehidrasi pada 42 pekerja, sebanyak $31(81,6 \%)$ pekerja yang bekerja lingkungan kerja yang mempunyai tekanan panas di atas NAB mengalami dehidrasi tingkat berat, 7 pekerja $(18,4 \%)$ mengalami dehidrasi tingkat ringan. Sedangkan pekerja yang bekerja di lingkungan kerja sesuai NAB, 1 pekerja $(25,0 \%)$ mengalami dehidrasi tingkat berat dan 3 pekerja $(75,0 \%)$ mengalami dehidrasi tingkat ringan. Hasil analisis 
Tabel 2. Analisis bivariat hubungan tekanan panas, konsumsi cairan, penggunaan pakaian saat bekerja dengan tingkat dehidrasi

\begin{tabular}{lc}
\hline \multicolumn{1}{c}{ Variabel } & $P$ value \\
\hline Hubungan tekanan panas dengan tingkat dehidrasi & 0,036 \\
Hubungan konsumsi cairan dengan tingkat dehidrasi & 0,021 \\
Hubungan penggunaan pakaian saat bekerja dengan tingkat dehidrasi & 0,020 \\
\hline
\end{tabular}

diperoleh nilai $p$ value sebesar 0,036 . Hal ini menunjukkan ada hubungan tekanan panas dengan tingkat dehidrasi pada pekerja dengan nilai OR 13,286 sehingga dapat disimpulkan tekanan panas merupakan faktor risiko terjadinya tingkat dehidrasi pada pekerja. Menurut Fajrin (2014) paparan suhu tinggi dapat menyebabkan hipotalamus merangsang kelenjar keringat untuk mengeluarkan keringat sebagai bentuk respon dari keadaan lingkungan sekitarnya, sehingga menyebabkan berkurangnya cairan dalam tubuh yang menyababkan rasa haus, letih dan dehidrasi. Kulit memiliki banyak fungsi, yang berguna dalam menjaga homeostasis tubuh. Fungsifungsi tersebut dapat dibedakan menjadi fungsi proteksi, absorpsi, ekskresi, persepsi, pengaturan suhu tubuh (termoregulasi), dan pembentukan vitamin D. Walaupun stratum korneum kedap air, namun sekitar $400 \mathrm{~mL}$ air dapat keluar dengan cara menguap melalui kelenjar keringat tiap hari.

Seorang yang bekerja dalam ruangan mengekskresikan $200 \mathrm{~mL}$ keringat tambahan, dan bagi orang yang aktif jumlahnya lebih banyak lagi. Selain mengeluarkan air dan panas, keringat juga merupakan sarana untuk mengekskresikan garam. Status hidrasi dipengaruhi oleh adanya faktor suhu lingkungan yang tinggi sehingga terjadi peningkatan pengeluaran cairan melalui pernapasan dan keringat yang menyebabkan kebutuhan cairan tubuh meningkat dan kecukupan konsumsi cairan yang sesuai dengan kebutuhan (Santoso, 2011)'(Veronica, 2010). Hal ini sejalan dengan penelitian yang dilakukan di industri pada pekerja laki-laki yang berada dilingkungan kerja dengan tekanan panas melebihi NAB yaitu sebanyak $52 \%$ pekerja mengalami dehidrasi (Andayani, 2013). Penelitian lain di Australia pada pekerja outdoor menunjukkan bahwa 79\% pekerja mengalami dehidrasi. Suhu lingkungan bekerja merupakan salah satu faktor yang menimbulkan keluhan dehidrasi (Fajrin, 2014).

Hal ini sejalan dengan penelitian yang dilakukan di industri pada pekerja laki-laki yang berada dilingkungan kerja dengan tekanan panas melebihi NAB yaitu sebanyak $52 \%$ pekerja mengalami dehidrasi (Andayani, 2013). Penelitian lain di Australia pada pekerja outdoor menunjukkan bahwa 79\% pekerja mengalami dehidrasi. Suhu lingkungan bekerja merupakan salah satu faktor yang menimbulkan keluhan dehidrasi (Fajrin, 2014). Akibat suhu lingkungan tinggi, suhu tubuh akan meningkat (tubuh mendapat pemanasan berlebih) maka akan terjadi vasoliditas pembuluh darah dan akan terjadi pengeluaran keringat yang akan disekresi ke pembuluh kulit (O'Callaghan C. At a Glance., 2009).

Hasil penelitian tentang hubungan konsumsi cairan dengan tingkat dehidrasi menunjukkan 30 pekerja $(83,3 \%)$ yang mengkonsumsi cairan $<1$ liter mengalami dehidrasi tingkat berat, sedangkan 6 pekerja $(16,7 \%)$ mengalami dehidras tingkat ringan. Pekerja yang mengkonsumsi cairan $\geq 1$ liter, 2 pekerja $(33,3 \%)$ mengalami dehidrasi tingkat berat dan 4 pekerja $(66,7 \%)$ mengalami dehidrasi tingkat ringan. Hasil analisis diperoleh nilai $p$ value sebesar 0,021 . Hal ini menunjukkan ada hubungan konsumsi cairan dengan tingkat dehidrasi pada pekerja dengan nilai OR 0,1 sehingga dapat disimpulkan konsumsi cairan merupakan faktor protektif terhadap terjadinya tingkat dehidrasi pada pekerja. Secara alami tubuh berkeringat menurunkan suhunya dan hal ini sanagt signifikan dalam mengurangi cairan tubuh. Bila cairan tubuh tidak digantikan maka pekerja akan mengalami dehidrasi dan meningkatkan risiko terhadap tekanan panas. Penting untuk meminum air sebelum, selama dan setelah bekerja di tempat yang panas (Suma'mur, 2009). Faktor yang mempengaruhi 
konsumsi air kurang diantaranya yaitu berkurangnya rasa haus, ketidakinginan untuk sering buang air kecil, ketidaksukaan subjek terhadap air putih dan lebih memilih mengonsumsi teh atau kopi, komposisi minuman non air putih yang dapat meningkatkan atau menurunkan rasa haus untuk mengkonsumsi air putih, sehingga berdampak terhadap cukup atau kurangnya pemenuhan cairan tubuh (Aprillia, 2014)'(Kant, 2009).

Bila kecukupan konsumsi cairan terpenuhi sesuai kebutuhan dalam lingkungan panas maka status hidrasi akan baik, sebaliknya jika konsumsi cairan kurang karena suhu lingkungan yang tinggi maka akan berisiko dehidrasi (Suma'mur, 2009). Hal ini sejalan dengan penelitian yang dilakukan pada 53 pekerja industri yang terpapar tekanan panas dari lingkungan kerja yaitu menunjukan adanya hubungan konsumsi cairan dengan dehidrasi (Sari, 2017). Penelitian yang dilakukan pada pekerja pandai besi menunjukkan hasil ada hubungan antara konsumsi air minum dengan keluhan subyektif dehidrasi akibat tekanan panas (Hidayat, 2016). Kebiasaan minum air yang tidak dilakukan dalam kurun waktu yang sering tetap memungkinkan terjadinya dehidrasi, meskipun jumlahnya cukup. Secara fisiologis, manusia sudah dibekali dengan respon untuk memasukkan cairan ke dalam tubuh. Respon haus merupakan refleks yang secara otomatis menjadi perintah kepada tubuh memasukkan cairan (Indra, 2013).

Hasil penelitian tentang hubungan penggunaan pakaian saat bekerja dengan tingkat dehidrasi menunjukkan 26 pekerja $(86,7 \%)$ yang tidak selalu menggunakan pakaian saat bekerja mengalami dehidrasi tingkat berat sedangkan 4 pekerja $(13,3 \%)$ mengalami dehidrasi tingkat ringan. Pekerja yang selalu menggunakan pakaian saat bekerja sebanyak 6 pekerja $(50,0 \%)$ mengalami dehidrasi tingkat berat dan 6 pekerja $(50 \%)$ mengalami dehidrasi tingkat ringan. Hasil analisis diperoleh nilai $p$ value sebesar 0,020 . Hal ini menunjukkan ada hubungan penggunaan pakaian saat bekerja dengan tingkat dehidrasi pada pekerja dengan nilai OR 0,154 sehingga dapat disimpulkan penggunaan pakaian saat bekerja merupakan faktor protektif terhadap terjadinya tingkat dehidrasi pada pekerja.Tidak menggunakan pakaian selama bekerja dilingkungan panas akan mempercepat proses penguapan dari dalam tubuh melalui pernafasan dan keringat, apabila hal tersebut tidak diimbangi dengan konsumsi cairan yang cukup maka akan menimbulkan dehidrasi. Hasil penelitian yang dilakukan pada pekerja di jepang menunjukkan tekanan panas ditempat kerja akan bertambah apabila pekerja menggunakan pakaian dengan kelembaban dan permeabilitas udara yang rendah dan kerja fisik yang berat. Apabila tidak diimbangi dengan asupan cairan yang cukup maka dapat menimbulkan dehidrasi (Horie, 2013). Hal tersebut dapat diminimalisir dengan cara pemilihan pakaian yang mudah menyerap keringat dan tidak kencang di tubuh dan konsumsi cairan yang cukup.

Hasil analisis multivariat menggunakan uji regresi logistik multivariat dapat dilihat di tabel 3. Diketahui bahwa faktor-faktor yang mempengaruhi teingkat dehidrasi tingkat dehidrasi pekerja industri pandai besi Desa Hadipolo adalah kategori konsumi cairan dan kategori penggunaan pakaian saat bekerja.

Logit $($ Tingkat Dehidrasi) $=7,563-2,744$ konsumsi cairan (1) - 2,241 penggunaan pakaian (1) Jadi peluang tingkat dehidrasi pada pekerja pandai besi jika konsumsi cairan " $<1$ liter" (kode 1) dan penggunaan pakaian saat bekerja "tidak selalu" (kode 1) adalah 92,93\%.

Logit $($ Tingkat Dehidrasi) $=7,563-2,744$ konsumsi cairan (2) - 2,241 penggunaan

Tabel 3. Variabel lolos model multivariat

\begin{tabular}{lccc}
\hline \multicolumn{1}{c}{ Variabel } & $\beta$ & P value & Exp $\beta$ \\
\hline Kategori konsumsi cairan & $-2,744$ & 0,016 & 0,064 \\
Kategori penggunaan pakaian saat bekerja & $-2,241$ & 0,017 & 0,106 \\
Konstanta & 7,563 & 0,001 & 1925,277 \\
\hline
\end{tabular}


pakaian (2) Jadi peluang tingkat dehidrasi pada pekerja pandai besi jika konsumsi cairan " $\geq 1$ liter" (kode 2) dan penggunaan pakaian saat bekerja "selalu" (kode 2) adalah 8,26\%.

Pekerja yang mengkonsumsi cairan $<1$ liter/hari dan tidak selalu menggunakan pakaian saat bekerja, maka memiliki probablitias untuk terkena dehidrasi sebesar $92,93 \%$ dibandingkan dengan pekerja yang mengkonsumsi cairan $\geq 1$ liter/hari dan selalu menggunakan pakaian saat bekerja yaitu probabilitas terkena dehidrasi sebesar 8,26\%. Dari persamaan tersebut dapat diartikan bahwa pekerja yang mengkonsumsi cairan $<1$ liter/hari dan tidak selalu menggunakan pakaian saat bekerja memiliki risiko dehidrasi 11,246 kali.

Hasil analisis multivariat yang dilakukan dari tiga varibel bebas dengan satu variabel terikat dapat diketahui bahwa variabel yang memiliki peran yaitu kategori konsumsi cairan dan kategori penggunaan pakaian saat bekerja. Suhu lingkungan yang tinggi meyebabkan suhu tubuh seseorang meningkat dan tubuh melakukan adaptasi dengan lingkungan dengan cara mengekskresikan keringat. Apabila ekskresi keringat terjadi secara terus menerus tanpa diimbangi dengan asupan air yang cukup maka dapat menyebabkan dehidrasi (Briawan, 2008). Pekerja yang mengonsumsi cairan dalam jumlah cukup atau sesuai dengan kebutuhan tubuh maka akan memiliki status hidrasi baik, sedangkan pekerja yang asupan cairannya tidak memenuhi kebutuhan dapat mengalami dehidrasi.

Sebagian besar pekerja di industri pandai besi Desa Hadipolo tidak menyadari bahwa status hidrasi mereka sudah tidak normal. Hal tersebut terjadi karena konsumsi cairan pekerja $>1$ liter selama 5 jam bekerja. Jumlah konsumsi cairan yang dikonsumsi pekerja masih kurang bila dibandingkan dengan jumlah yang dianjurkan yaitu di mana seorang yang bekerja di tempat panas sebaiknya minum sebanyak 200-300 cc/30 menit atau setara dengan 1 gelas kemasan/30 menit (Fajrianti, 2017). Asupan cairan yang tidak memenuhi kebutuhan cairan tubuh dapat terjadi karena faktor kebiasaan minum pekerja. Pada pekerja dalam lingkungan panas harus lebih memperhatikan frekuensi minum yang lebih sering.

Penelitian yang dilakukan Andayani (2013) pada pekerja pabrik menunjukkan bahwa apabila konsumsi cairan pekerja baik maka status hidrasi akan semakin baik. Penelitian ini mendukung teori kehilangan air sangat banyak dari tubuh dalam bentuk keringat adalah untuk tujuan pendinginan dengan cara penguapan. Air minum harus disediakan bagi tenaga kerja yang bekerja di lingkungan tempat kerja panas, dengan cara seperti itu pekerja didorong untuk minum dalam jumlah sedikit-sedikit tetapi sering dilakukan, misalnya satu gelas setiap 20 sampai dengan 30 menit. Tenaga kerja yang hanya minum bila merasa haus saja tidak akan memberikan hasil yang memuaskan. Padahal haus merupakan respon bahwa tubuh telah kehilangan cairan sebesar $1-2 \%$ berat badan tubuh. Respon tersebut dikendalikan oleh sistem saraf pusat. Saat terlambat minum, air tubuh menurun, dan osmolalitas cairan tubuh meningkat. Ada perbedaan waktu antara tubuh mulai kekurangan air dengan muncul rasa haus. Haus muncul setelah beberapa menit organ tubuh utama kekurangan air dan memberi sinyal ke hipotalamus. Seharusnya seseorang mengonsumsi cairan sebelum merasa haus, tetapi hanya sebagian kecil pekerja yang minum sebelum merasa haus (Andita, 2018).

Pakaian adalah salah satu hal yang mempengaruhi kondisi panas tubuh pada beraktivitas. Pada iklim panas, pakaian berfungsi untuk menjaga tubuh dari paparan sinar matahari atau berbagai dampak lainnya. Pakaian bertindak sebagai penghalang yang menghambat penguapan serta mengurangi kehilangan panas tubuh dengan mengurangi sirkulasi udara di dekat kulit, sehingga pakaian yang memiliki kemampuan penguapan yang baik akan menguntungkan pada saat beraktivitas. Semakin tinggi permeabilitas uap air suatu pakaian maka semakin tinggi pula kemampuannya dalam menyerap keringat. Kondisi ini menguntungkan pada saat bekerja karena dengan kemampuan dalam menyerap keringat maka dapat menurunkan core dan skin 
temperature dengan cepat. Hal ini sejalan dengan penelitian yang dilakukan pada responden lakilaki yang menggunakan jenis pakaian yang berbeda pada saat berolahraga di lingkungan panas, hasil penelitian menunjukkan adanya perbedaan absrobsi keringat pada 2 jenis pakaian (Faradilla, 2018).

Pakaian yang digunakan oleh orang Indonesia saat ini sangat bervariasi tetapi mayoritas menggunakan pakaian yang berbeda jenis bahan di lingkungan yang sama (Faradilla, 2018). Kondisi lingkungan, tekanan udara, aktivitas fisik dan suhu permukaan dalam pakaian adalah penentu perolehan panas atau kehilangan panas oleh kulit yang tertutup oleh pakaian. Pakaian yang dipakai pada pekerja pandai besi berguna untuk melindungi tubuh dari pajanan panas dan radiasi yang dihasilkan oleh tungku pembakaran. Apabila pekerja tidak menggunakan pakaian atau menggunakan pakaian dengan bahan yang tidak tepat dan ketat maka dapat menimbulkan tingkat keringat yang tak terduga sehingga menimbulkan kebutuhan cairan yang lebih banyak. Hal tersebut apabila tidak diimbangi dengan konsumsi cairan yang cukup makan dapat menimbulkan dehidrasi (Kenefick, 2012).

\section{PENUTUP}

Simpulan penelitian ini adalah variabel yang paling berperan terhadap tingkat dehidrasi yaitu kategori konsumsi cairan dan penggunaan pakaian saat bekerja. Hal yang perlu di kaji lebih lanjut untuk peneliti selanjutnya adalah melakukan observasi konsumsi cairan bukan hanya dari minuman saja tetapi juga dari makanan dan melakukan observasi terhadap bahan pakaian yang digunakan oleh pekerja pada saat bekerja.

\section{DAFTAR PUSTAKA}

Andayani, K. dan Dieny, F.F. 2013. Hubungan Konsumsi Cairan dengan Status Hidrasi pada Pekerja Industri Laki-Laki. Journal of Nutrition College, 2(4): 622-629.

Andita, S., Dina, R. P., Aruben, R. 2018. Hubugan Asupan Energi, Protein, Status Gizi, dan Suhu
Lingkungan Dengan Produktivitas Kerja. Jurnal Kesehatan Masyarakat, 6(5): 422-428.

Aprillia, D.D. dan Khomsan, A. 2014. Konsumsi Air Putih, Status Gizi, dan Status Kesehatan Penghuni Panti Werda di Kabupaten Pacitan. Jurnal Gizi Pangan, 9(3): 167-172.

Apriyani, A. 2014. Pengaruh Iklim Kerja Terhadap Dehidrasi Pada Karyawan Unit Workshop PT. Indo Acidatama Tbk, Kemiri, Kebakkramat, Karanganyar. Jurnal Media Gizi Indonesia, 2(9): 1467-1475.

Brazaitis, M., Kamandulis, S., Skurvydas, A. 2010. The Effect Of Two Kinds Of T-Shirts On Physiological And Psychological Thermal Responses During Exercise And Recovery. Jounal Of Ergonomics, 42(1): 46-51.

Briawan, C.D. 2008. Studi Kebiasaan Minum dan Hidrasi pada Remaja dan Dewasa di Dua Wilayah Ekologi yang Berbeda. Jurnal Pergizi Pangan Indonesia, 5(2): 1-5.

Dai, X.Q., Imamura, R., Liu, G.L., Zhou, F. 2008. Effect Of Moisture Transport On Microclimate Under T-Shirts. European Journal Of Applied Physiologi, 104(2): 37-40.

Davis, J. K. and Bhisop, P. A. 2013. Impact Of Clothing On Exercise In The Heat. Journal Of Sports Medicine, 43(8): 695-706.

Fajrianti, G., Shaluhiyah, Z., Lestantyo, D. 2017. Pengendalian Heat Stress Pada Tenaga Kerja di Bagian Furnace PT. X Pangkalpinang Bangka Belitung. Jurnal Promosi Kesehatan Indonesia, 12(2): 150-162.

Fajrin, N. 2014. Faktor yang Berhubungan dengan Keluhan Kesehatan Akibat Tekanan Panas pada Pekerja Instalasi Laundry Rumah Sakit di Kota Makassar. Journal of Public health, 2(5): $1-11$.

Faradilla, A. dan Putrianto, N.K. 2018. Pengaruh Jenis Bahan Pakaian Terhadap Respon Fisiologi dan Psikologi Manusia pada Saat Berolahraga di Lingkungan Panas. Jurnal Teknik dan Ilmu komputer, 7(26): 191-200.

Gustam. 2012. Faktor Risiko Dehidrasi Pada Remaja dan Dewasa. Skripsi. Bogor: Institut Pertanian Bogor.

Harrianto, R.. 2008. Buku Ajar Kesehatan Kerja. Jakarta: EGC.

Hasani, Y. 2016. Perbedaan Kebutuhan Air Minum Dan Kelelahan Kerja Pada Pekerja Terpapar Iklim Kerja Panas Di Bagian Pengecoran Logam dan Finishing PT. Aneka Adhilogam Karya Ceper Klaten. Jurnal Kesehatan Masyarakat, 1(2): 1-12. 
Hastuti, Y.D., Nasution, E., Aritonang, E. 2015. Perilaku Konsumsi Air Minum Pada Siswa/Siswi SMA Negeri Medan Tahun 2015. Jurnal Kesehatan Masyarakat, 1(2): 1-6.

Hidayat, R.A. 2016. Hubungan Konsumsi Air Minum Dengan Keluhan Subjektif Akibat Tekanan Panas pada Pekerja Pandai Besi Di Desa Bantaran Probolinggo. Jurnal Keperawatan Muhammadiyah, 1(1): 32-43.

Hidayatullah, A.W. 2016. Perbedaan Tingkat Dehidrasi, Tekanan Darah, dan Gangguan Kesehatan pada Pekerja Terpapar Iklim Kerja Panas di Atas dan di Bawah NAB pada Bagian Produksi PT. Iskandar Indah Printing Textile Surakarta. Journal of Public health, 3(2): $1-15$.

Horie, S. 2013. Prevention of Musculoskeletal Disorders in the Workplace. Journal of Japan Medical Association, 56(3): 186-192.

Indra., Naiem, M. F., Wahyuni, A. 2013. Determinan Keluhan Akibat Tekanan Panas Pada Pekerja Bagian Dapur Rumah Sakit di Kota Makassar. Journal of Chemical Information and Modeling, 53(9): 1689-1699.

Kant, A. K., Graubard, B. I., Atchison, E. A. 2009. Intakes Of Plain Water, Moisture In Foods And Beverages, And Total Water In The Adult US Population-Nutritional, Meal Pattern, And Body Weight Correlates: National Health And Nutrition Examination Surveys 1999-2006. American Journal of Clinical Nutrition, 90(3): 655-663.

Kenefick, R.W., Cheuvront, S.N., Leon, L.R., O'brien, K.K. 2012. Dehydration and Rehydration. United State Army Research Institute of Environmental Medicine, 298(8): 7186.

Kukus, Y., Supit, W., Lintong, F. 2009. Suhu Tubuh: Homeostasis Dan Efek Terhadap Kinerja Tubuh Manusia. Jurnal Biomedik, 1(2): 107118

Lestari, S. 2016. Perbedaan Tingkat Dehidrasi dan Kelelahan pada Karyawan Terpapar Iklim Kerja Melebihi NAB (Stock Yard) dengan Sesuai NAB (Produksi Jalur 2) di PT. Wijaya Karya Beton Tbk PPB Majalengka. Journal of Public health, 7(4): 1-14.

Ningsih, S. W. K. 2014. Perbedaan Kebiasaan Minum dan Status Hidrasi pada Remaja
Overweight di SMK Batik 1 Surakarta. Journal of Public health, 6(2): 1-13.

O'Callaghan, C. 2009. Sistem Ginjal: Kelainan Metabolisme Natrium dan Air, Gagal Ginjal Kronik: Komplikasi Klinis dan Tata Laksananya. Jakarta: Erlangga Medical Series.

OSHA. 2011. Preventing Heat Stress in At-Risk Worker. Journal Environment of Care, 14(6): 1012.

Santoso, B. I. 2011. Air Bagi Kesehatan. Jakarta: Centra Communications.

Sari, M. P. 2017. Iklim Kerja Panas dan Konsumsi Air Minum Saat Kerja Terhadap Dehidrasi. Higeia Journal of Public Health Research and Development, 1(1): 51-57.

Sari, N.P. 2014. Pengaruh Iklim Kerja Panas Terhadap Dehidrasi dan Kelelahan Pada Tenaga Kerja Bagian Boiler di PT. Albasia Sejahtera Mandiri Kabupaten Semarang. Journal of Nutrition College, 5(6): 12-20.

Suma'mur, P. K. 2009. Hygiene Perusahaan dan Kesehatan Kerja (Hiperkes). Jakarta: Sagung Seto.

Tamsuri, A. 2009. Klien Gangguan Keseimbangan Cairan dan Elektrolit. 1st edn. Edited by E. A. Mardella. Jakarta: EGC.

Tasyrifah, G.M. 2017. Perbedaan Tingkat Dehidrasi dan Kelelahan Kerja pada Pekerja Terpapar Iklim Panas di Bagian Pengepakan dan Pelintingan di PT. Panen Boyolali. Journal of Public Health, 5(3): 1-14.

Vanani, N.S. 2008. Gambaran Tekanan Panas dan Keluhan Subyektif pada Pekerja di Bagian Curing PT. Multistrada Arah Sarana, TBK. Skripsi. Jakarta: Universitas Indonesia

Veronica, S. 2010. Hydration. Journal Occupational Hygine, 54(2): 134-136.

Wesseling, C. 2016. Heat Stress, Hydration And Uric Acid: A Cross-Sectional Study In Workers Of Three Occupations In A Hotspot Of Mesoamerican Nephropathy In Nicaragua. BMJ Open, 10(9): 1-11.

Wulandari, K., Widjasena, Baju., Ekawati. 2016. Hubungan Beban Kerja Fisik Manual dan Iklim Kerja Terhadap Kelelahan Pekerja Konstruksi Bagian Project Renovasi Workshop Mekanik. Jurnal Kesehatan Masyarakat, 4(3): 425-435. 